\title{
Reduced killer cell activity of lymphocytes from patients with asbestosis
}

\author{
M KUBOTA, ${ }^{1}$ S KAGAMIMORI,${ }^{2} \mathrm{~K}$ YOKOYAMA,${ }^{3}$ AND A OKADA ${ }^{1}$
}

From the Department of Public Health, ${ }^{1}$ School of Medicine, Kanazawa University, Kanazawa, Department of Community Medicine, ${ }^{2}$ Toyama Medical Pharmaceutical University, Toyama, and Internal Medicine, ${ }^{3}$ National Sanatorium Kinki Chuo Hospital, Osaka, Japan

ABSTRACT Immunological abnormalities in 30 patients with asbestosis were investigated by examining the cytotoxicity of natural killer (NK) cells and antibody dependent cellular cytotoxicity by killer $(\mathrm{K})$ cells from peripheral blood lymphocytes; the effects of interferon on NK activity was also examined. Fifteen men and 15 women (mean age 58; range 40-72) with asbestosis but who were free of complications such as tuberculosis, carcinoma, or steroid treatment were the subjects for study. There were nine cases of type 1,19 cases of type 2, and two cases of type 3 disease as described in the ILO classification of pneumoconiosis. They were ail textile workers with a mean duration of 18 years (3-40 years) since first exposure to chrysotile. Controls matched for age and sex were selected from a population without occupational exposure to asbestos. The activity of the NK and $\mathrm{K}$ cells in patients with asbestosis was significantly lower than in the control group, but the populations of NK and $\mathrm{K}$ cells in the peripheral blood lymphocytes were not significantly different in the two groups. An in vitro experiment showed that the increase in the cytotoxicity of the NK cell after treatment with interferon- $\alpha$ was significantly lower in the subjects than in the controls. These results indicate that one of the defence mechanisms in relation to cancer is deficient in patients with asbestosis.

The inhalation of asbestos is associated with asbestosis, lung cancer, and pleural mesothelioma. Several studies have helped to clarify the pathological mechanisms of these lung disorders; the effects of dust on human defence mechanisms have also been investigated..$^{-6}$ Natural killer (NK) cell and antibody dependent cellular cytotoxicity (ADCC) by killer $(\mathrm{K})$ cell are thought to be the mediators of the first line of defence against cancer cells, or cells infected with virus. ${ }^{7-9}$ Furthermore interferon has recently been found to have a regulatory role in NK cell activity. ${ }^{10}$ Several aspects of this defence mechanism have been reported to be abnormal in patients with autoimmune disease $\mathrm{e}^{1-14}$ and cancer ${ }^{15} 10$ but it is not known if there are any defects in NK cell function or ADCC in patients with asbestosis. In the present study we have investigated NK cell and ADCC activity in peripheral blood lymphocytes from patients with asbestosis. We have also assessed the response of the NK cell to exogenous IFN- $\alpha$ in vitro.

Received 2 May 1984

Accepted 11 July 1984

\section{Materials and methods}

PATIENTS WITH ASBESTOSIS AND CONTROLS Thirty patients with asbestosis in Kinki Chuo Hospital were the subjects for the study. The 15 men and 15 women (mean age 58; range 40-72) were otherwise free of complications such as tuberculosis, carcinoma, or steroid treatment. There were nine cases of type 1,19 cases of type 2 , and two cases of type 3 as described in the ILO classification of pneumoconiosis. All were textile workers with a mean duration of 18 years (3-40 years) since first exposure to chrysotile. Controls matched for age and sex were selected from a population without occupational exposure to asbestos. There was no significant difference in the smoking habits of the patients or the controls.

\section{PREPARATION OF PERIPHERAL BLOOD}

LYMPHOCYTES

Heparinised whole blood was obtained from all subjects and peripheral blood lymphocytes were separated with Ficoll-Hypaque (Lymphocyte Separation 
Medium, Bionetics, Kensington), washed twice with Hanks balanced solution, and suspended in RPMI 1640 medium containing $10 \%$ fetal calf serum (FCS, Microbiological Associates, Maryland).

\section{ASSAY OF NK CELL ACTIVITY}

NK activity was tested against the human myeloid cell line K-562. Target cells were maintained in RPMI 1640 medium containing $10 \%$ FCS and were passaged two to three times a week. Target cell labelling was performed by incubating $5 \times 10^{6}$ cells with $100 \mu \mathrm{Ci}$ of sodium chromate $\left({ }^{51} \mathrm{Cr}\right)$ for 60 minutes at $37^{\circ} \mathrm{C}$; cells were then washed twice and resuspended at the concentration of $1 \times 10^{5} \mathrm{cells} / \mathrm{ml}$ in $10 \%$ FCS-RPMI medium. One hundred microlitres of this cell suspension $\left(1 \times 10^{4}{ }^{51} \mathrm{Cr}\right.$-labelled K-562 cells) were added to each tube. Peripheral blood lymphocytes were tested in duplicate at effector:target ratios of 20:1. Autologous controls (labelled targets only) were used to determine spontaneous release (SR) in all experiments. Tubes were incubated for 10 hours at $37^{\circ} \mathrm{C}$ in $5 \% \mathrm{CO}_{2}$ humidified air. Total counts were determined by direct measurement of $\mathrm{cpm}$ present in $10^{4}{ }^{51} \mathrm{Cr}$ labelled K-562 cells. Specific release was calculated according to the formula:

Per cent specific release $=\frac{\mathrm{cpm} \text { Experimental }-\mathrm{cpm} \mathrm{SR}}{\mathrm{cpm} \text { Total counts }-\mathrm{cpm} \mathrm{SR}} \times 100$

Per cent specific release was transformed to $\theta$ values for statistical treatment.

\section{PRETREATMENT OF EFFECTOR CELLS WITH INTERFERON}

Effector cells (peripheral blood lymphocytes) were resuspended to give cell concentrations of $2.5 \times 10^{5}$ cells $/ \mathrm{ml}$ and $0.8 \mathrm{ml}$ of the suspension was added to tubes (in triplicate). Before the addition of target cell (K-562), 200 units of interferon in $0.2 \mathrm{ml}$ RPMI 1640 were added. Prepared interferon was the IFN- $\alpha$ type induced in human leucocytes from the Green Cross Corporation of Japan. After incubation of 10 hours, per cent specific release was determined as described above.

\section{ASSAY OF ADCC}

The technique followed that of MacLennan et al. ${ }^{17}$ Chang cells, a monolayer cell line derived from human hepatoma cells, were used as targets. Chang cells grown in Eagle's medium MEM with $10 \%$ FCS were pooled after mitotic harvest. The cells were washed and resuspended to a total of $5 \times 10^{6}$ cells with $100 \mu \mathrm{Ci}$ of ${ }^{51} \mathrm{Cr}$ for 90 minutes at $37^{\circ} \mathrm{C}$; the cells were then washed three times and resuspended at a concentration of $1 \times 10^{4}$ cells $/ \mathrm{ml}$ in Eagle's medium MEM with $10 \%$ FCS. Either rabbit anti-
Chang serum or normal rabbit serum was added, giving a serum dilution of $10^{-4}$.

To each tube, $1.0 \mathrm{ml}$ of peripheral blood lymphocytes suspension was added to $1.0 \mathrm{ml}$ of labelled Chang cells with or without antibody. Peripheral blood lymphocytes were tested in duplicate at effector:target ratios of 20:1. The tubes were incubated for 12 hours at $37^{\circ} \mathrm{C}$ in $5 \% \mathrm{CO}_{2}$ humidified air. Total counts were determined using the calculations as for the assay NK cell activity (see above).

\section{ANALYSIS OF NK CELL POPULATIONS WITH THE FLUORESCENCE ACTIVATED CELL SORTER} Immunofluorescence analyses were performed with a computerised cell analysing and sorting system (Cytofluorograf system $50 \mathrm{H}$, Ortho Co Ltd).

Leu 7 monoclonal antibody (B/D Co Ltd), was conjugated to fluorescein isothiocyanate with a final fluorescein/protein ratio of 5.4. For direct immunofluorescent staining, $10 \mu \mathrm{l}$ whole blood was added to the solution of the monoclonal antibodies and incubated on ice for 25 minutes. After this, $2 \mathrm{ml}$ of lysing solution $\left(8.3 \mathrm{~g}\right.$ of $\mathrm{NH}_{4} \mathrm{Cl}, 1 \mathrm{~g}$ of $\mathrm{KHCO}_{3}$, and $0.37 \mathrm{~g}$ of $\mathrm{Na}$ EDTA, $\mathrm{pH} 7.4$ per litre) were added to the sample for 5-10 minutes at room temperature; the sample was analysed without delay with the fluorescence activated cell sorter.

\section{Results}

COMPARISON OF NK AND K CELL POPULATIONS

Figure 1 shows the percentage of target cell lysis produced by the peripheral blood lymphocytes from controls and patients with asbestosis in the $\mathrm{K}-562$ and Chang cells. NK cell activity in patients with asbestosis was $42.5 \pm 1 \cdot 8$ (mean $\pm \mathrm{SE}$ ) whereas that in the controls was $56 \cdot 3 \pm 2 \cdot 1$. Furthermore, ADCC in patients with asbestosis was $30.9 \pm 2.0$ (mean \pm SE) compared with $38.6 \pm 1 \cdot 1$ in the controls. NK cell activity and ADCC in patients with asbestosis was significantly lower than in the controls $(p<$ $0 \cdot 001$ ).

The relation between NK cell activity and ADCC was examined in patients and controls (fig 2). A correlation coefficient of $r=0.61(p<0.01)$ between NK cell activity and ADCC was found in the controls. The correlation between NK cell activity and ADCC in patients with asbestosis was also statistically significant $(r=0.56, p<0.01)$. The correlation coefficients of both controls and patients with asbestosis were compared using the $\mathrm{Z}$ transformation of the correlation coefficient but were not significantly different.

As shown in fig 3, there was no significant difference in the population of Leu- $7^{+}$cells in patients or controls showing that there was no difference in the 
EFFECT OF IFN- $\alpha$ ON NK CELL ACTIVITY

Previous studies have shown that the cytotoxicity of human and murine NK cells can be enhanced by interferon. $^{1819}$ We therefore tested the ability of human IFN- $\alpha$ to augment the activity of NK cells

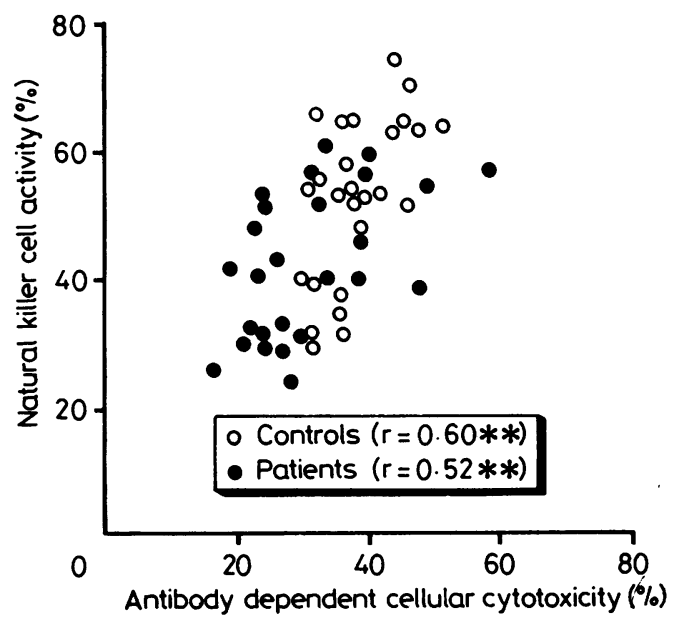

Fig 2 Correlation between NK cell activity and ADCC in controls and patients with asbestosis. ${ }^{* *} p<0.01$. from patients with asbestosis. The NK cell activity of nine controls increased with the addition of IFN- $\alpha$ and was unchanged in one other (fig 4). In three of the ten patients with asbestosis the NK cell activity was enhanced; in the remaining seven it was not (fig 4). These results indicate that in many patients with asbestosis there is no response to exogenous IFN- $\alpha$.

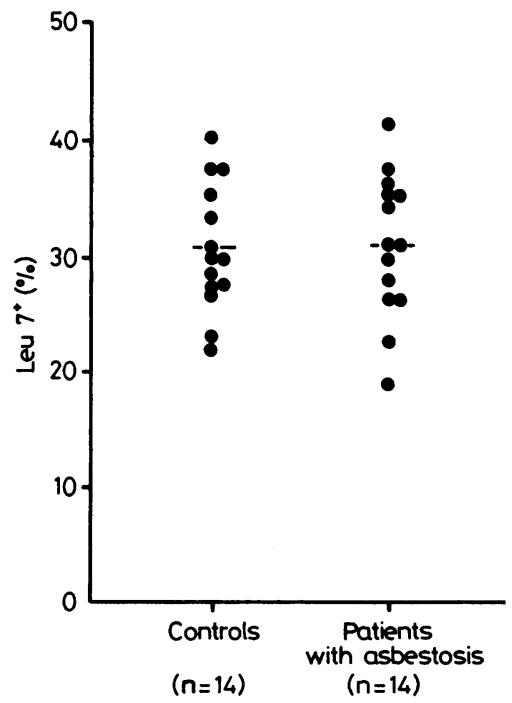

Fig 3 Populations of NK cells in controls and patients with asbestosis using monoclonal antibodies (Leu 7). 


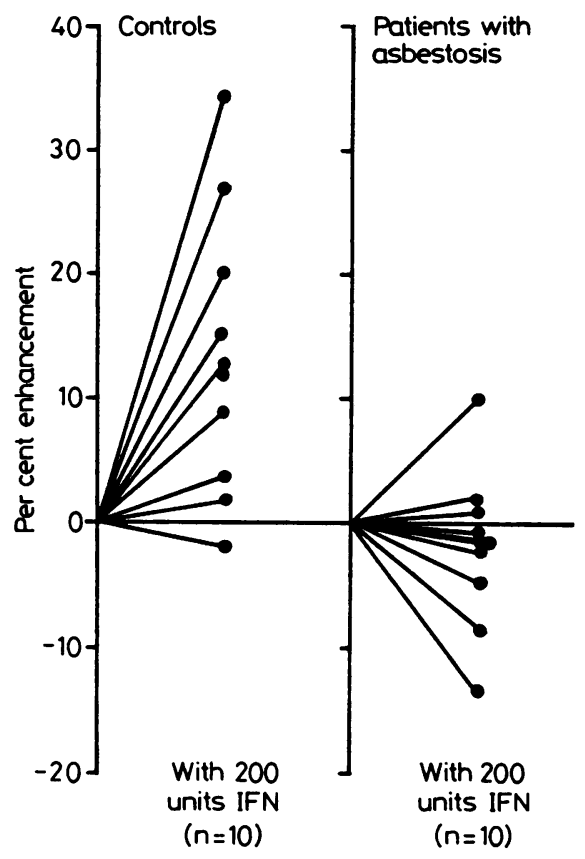

Fig 4 Effect of 200 units of interferon on NK cell activity in controls and patients with asbestosis.

\section{Discussion}

A relation between asbestosis and pleural mesothelioma, cancer of the lung, and other organs has been established in man and supported by animal experiments. ${ }^{20-23}$ In recent studies abnormalities in the defence of mechanisms of the body have been related to asbestosis. These include an abnormally high level of serum immunoglobulin, the depression of cellular immunity, and the development of autoimmune antibodies. ${ }^{1-6}$

Furthermore, since the NK and $\mathrm{K}$ cells and interferon have been found to be components of the non-immunological defence mechanisms, we have investigated their activity in patients with asbestosis; abnormalities have already been reported in some autoimmune diseases and cancers. ${ }^{11-16}$ As the influence of sex and age on NK and $K$ cell activity is not well known, controls matched for sex and age with the patients with asbestosis were also included. We found a reduction in NK and $K$ cell activity in the patients with asbestosis. Nevertheless, since the number of NK and $K$ cells did not differ from that of the controls, the reduced activity was due to a lower cytotoxicity per cell. In addition, a significant correlation between NK and $K$ cell activities in the patients with asbestosis indicated that the activities of both were simultaneously reduced.
Recent studies have shown that there is a regulatory circuit affecting the NK cell and interferon ${ }^{24}$ and so we investigated the ability of human IFN- $\alpha$ to augment NK cell activity. It was found that exogenous IFN- $\alpha$ failed to enhance the NK cell activity of peripheral blood lymphocytes from patients with asbestosis. In previous work on NK cell activity and interferon in patients with asbestosis we have found that the serum IFN- $\alpha$ level, which was significantly higher than in controls, was negatively correlated with NK cell activity. ${ }^{25}$ The NK cell of a healthy person has a producing function of endogeneous IFN- $\alpha$, and exogeneous IFN- $\alpha$ enhances the NK cell activity of a healthy person. But the NK cell of patients with asbestosis has reduced both functions. These findings indicate that defects in nonimmunological defence mechanisms may develop in patients with asbestosis.

\section{References}

' Turner-Warwick M. Immunology and asbestosis. Proc $R$ Soc Med 1973;66:927-30.

${ }^{2}$ Kagan E, Solomon A, Cochrane JC, et al. Immunological studies of patients with asbestosis. I. Studies of cellmediated immunity. Clin Exp Immunol 1977;28:261-7.

${ }^{3}$ Kagan E, Solomon A, Cochrane JC, et al. Immunological studies of patients with asbestosis. II. Studies of circulating lymphoid cell numbers and humoral immunity. Clin Exp Immunol 1977;28:268-75.

${ }^{4}$ Haslam PL, Lukoszek A, Merchant JA, Turner-Warwick M. Lymphocyte responses to phytohaemagglutinin in patients with asbestosis and pleural mesothelioma. Clin Exp Immunol 1978;31:178-88.

${ }^{5}$ Lang A. An epidemiological survey of immunological abnormalities in asbestos workers. I. Nonorgan and organ-specific autoantibodies. Environ Res 1980;22:162-75.

- Lang A. An epidemiological survey of immunological abnormalities in asbestos workers. II. Serum immunoglobulin levels. Environ Res 1980;22:176-83.

${ }^{7}$ Kiessling R, Haller O. Natural killer cells in the mouse: an alternative immune serveillance mechanism? Contemp Top Immunobiol 1978;8:171-201.

Santoli D, Koprowski $\mathbf{H}$. Mechanisms of activation of human natural killer cells against tumor and virus-infected cells. Immunol Rev 1979;44:125-63.

${ }^{-}$Herberman RB. Natural killer (NK) cells and their possible roles in resistance against disease. Clin Immunol Rev 1981;1:1-65.

${ }^{10}$ Targan S, Dorey F. Dual mechanism of interferon augmentation of natural killer cytotoxicity (NKCC). Ann NY Acad Sci 1980;350:121-9.

"Makoto G, Kiyoaki T, Yoshihiko H. Natural cell mediated cytotoxicity in systemic lupus erythematosus. Arthritis Rheum 1980;23:1274-81.

12 Neighbour PA, Grayzel AI. Interferon production in vitro by leucocytes from patients with systemic lupus erythematosus and rheumatoid arthritis. Clin Exp Immunol 1981;45:576-82.

13 Tsokos GC, Rook AH, Djeu JY, Balow JE. Natural killer cells and interferon responses in patients with systemic lupus erythematosus. Clin Exp Immunol 1982;50:239-45.

14 Stöger I, Tälas M, Benczúr M, Gyódo E, Petrányi GG. Lack of correlation between impaired interferon production and natural killer activity of lymphocytes in multiple sclerosis. Arch Virol 1982;71:259-65. 
is Kadish AS, Doyle AT, Steinhauer EH, Ghossein NA. Natural cytoxicity and interferon production in human cancer: deficient natural killer activity and normal interferon production in patients with advanced disease. J Immunol 1981;127:1817-22.

${ }^{16}$ Hahn T, Levin S. The interferon system in patients with malignant disease. $J$ Interferon Res 1982;2:97-102.

${ }^{17}$ MacLennan ICM, Campbell AC, Gale DG. Quantitation of K cells. In: Bloom BR, David JR, eds. In vitro methods in cellmediated and tumor immunity. New York, San Francisco, London: Academic Press, 1976:511.

${ }^{18}$ Trinchieri G, Santoli D. Antiviral activity induced by culturing lymphocytes with tumor derived or virus-transferred cells. Enhancement of human natural killer cell activity by interferon and antagonistic inhibition of suspectibility of target cells to lysis. J Exp Med 1978;147:1314-33.

${ }^{19}$ Djeu JY, Heinbaugh JA, Holden HT, Herberman RB. Augmentation of mouse natural killer cell activity by interferon and interferon inducers. J Immunol 1979;122:175-81.
${ }^{20}$ Wagner JC, Sleggs CA, Marchand P. Diffuse pleural mesothelioma and asbestos exposure in the North Western Cape Province. Br J Ind Med 1960; 17:260-71.

${ }^{21}$ Lunch KM, Smith WA. Pulmonary asbestosis. III. Carcinoma of lung in asbesto-silicosis. Am J Cancer 1935;24:56-64.

${ }^{22}$ Lee DHK. Biological effects of ingested asbestos; report commentary. Environ Health Perspect 1974;9:113-7.

${ }^{23}$ Wagner JC. Experimental production of mesothelial tumors of the pleura by implantation of dusts in laboratory animals. Nature 1962;196:180-1.

${ }^{24}$ Djeu JY, Herberman RB. Augmentation of natural killer cell activity and induction of interferon by tumour cells and other biological response modifiers. In: Chirigos MA, Michell M, Mastrangelo MJ, Kvein M, eds. Mediation of cellular immunity in cancer by immune modifiers. New York: Raven Press, 1981:161.

${ }^{25}$ Kagamimori S, Watanabe M, Kubota M, Okada A. Serum interferon levels and natural killer cell activity in patients with asbestosis. Thorax (in press).

\section{The March 1985 issue}

\section{THE MARCH 1985 ISSUE CONTAINS THE FOLLOWING PAPERS}

\section{Editorial}

Biological exposure limits: the fetus and EEC politics R L ZIELHUIS

Minor psychiatric morbidity in employed young men and women and its contribution to sickness absence RACHEL JENKINS

Experimental study on the enhancement of the neurotoxicity of methyl n-butyl ketone by nonneurotoxic aliphatic monoketones J MISUMI AND M NAGANO

Partition coefficients of some industrial aliphatic hydrocarbons (C5-C7) in blood and human tissues L PERBELLINI, F BRUGNONE, D CARETTA, AND G MARANELLI

Total contribution of airborne lead to blood lead W I MANTON

Neurophysiological studies on workers exposed to lead J JEYARATNAM, G DEVATHASAN, CN ONG, W O PHOON, AND P K WONG

Recovery from paraquat pneumonitis J J SEIDENFELD, R E SOBONYA, AND JANICE M TOYOSHIMA

Gassings due to methylene chloride, xylene, toluene, and styrene reported to Her Majesty's Fac- tory Inspectorate 1961-80 M A BAKINSON AND R D JONES

Cancer morbidity among workers in the telecommunications industry D VÅGERÖ, A AHLBOM, R OLIN, AND S SAHLSTEN

Ventilatory responses of normal subjects to flax dust inhalation: the protective effect of autoclaving the flax J P JAMISON, J H M LANGLANDS, AND C C BODEL

Determinants of changes in $\mathrm{FEV}_{1}$ over a workshift D A ENARSON AND MOIRA YEUNG

Statistical derivation of a standardised procedure for counting expectorated alveolar macrophages as indicators of occupational air pollution A M NILSEN AND $S$ ENGEN

Short reports

Dysbaric hazard of a new fishing method in Hong 을. Kong: case report THLAM, KPYAU, AND N F J O'KELLY

Mortality experience of electrical engineers R OLIN, D VÅGERÖ, AND A AHLBOM

Correspondence

Allergy to laboratory animals ASSOCIATION, TAVISTOCK SQUARE, LONDON WC1H 9JR, price $£ 4.25$ (USA \$9.20), including postage. 